\title{
The Interrelations among Self-efficacy, Happiness, Individual Values, and Attractiveness Promoting Behavior
}

\author{
Vesarach Aumeboonsuke ${ }^{1}$ \\ ${ }^{1}$ International College, National Institute of Development and Administration, Thailand \\ Correspondence: Vesarach Aumeboonsuke. E-mail: vesarach@gmail.com
}

Received: December 6, 2017

Accepted: December 18, 2017

Online Published: February 26, 2018

doi:10.5539/ass.v14n3p37

URL: https://doi.org/10.5539/ass.v14n3p37

\begin{abstract}
The paper aims to investigate the associations among self-efficacy, happiness, individual values and attractiveness promoting behavior. The impact of self-efficacy and happiness on individual values and attractiveness promoting behavior is analyzed through the partial least squared structural equation modeling (PLS-SEM). The findings provide important implications that both self-efficacy and happiness are important in one's life but they play different and independent roles. The results found that individual values and attractiveness promoting behavior are independent and they have no significant association with each other. In essence, there is no one perfect solution for all quests. In order for an individual to attain higher level of individual values, psychological and mental factor like happiness should be paid much more attention than perceived ability like self-efficacy. However, self-efficacy is the key factor for an individual to engage oneself in behavior that promote his/her attractiveness.
\end{abstract}

Keywords: Attractiveness promoting behaviors, Happiness, Individual values, PLS-SEM, Self-efficacy

\section{Introduction}

The paper aims to investigate the associations among self-efficacy, happiness, individual values and attractiveness promoting behavior. Firstly, it proposes significant impact of self-efficacy and happiness on individual values. Secondly, it tests whether self-efficacy and happiness lead to attractiveness promoting behavior through the interaction effect with individual values. The impact of self-efficacy and happiness on individual values and attractiveness promoting behavior is analyzed through the partial least squared method performed and cross-checked in WARPLS and R programs.

\subsection{The importance of Attractiveness}

Attractiveness is the perception of the physical traits of an individual human person as pleasing or beautiful. It can include various implications, such as sexual attractiveness, cuteness, similarity and physique. Judgment of attractiveness of physical traits is partly universal to all human cultures, partly dependent on culture or society or time period, partly biological, and partly subjective and individual (Hönekopp, 2006).

Although attractiveness seems to be subjective, contrary to popular belief, societies generally agree on who is and who is not attractive, even across different cultures. According to several studies, individuals that are more attractive are perceived to be healthier, having better genes, more persuasive, more intelligent, and more successful. In essence, attractiveness is rewarded by societies.

Attractiveness is not just given by nature but it can be self-developed. Behaviors that can promote attractiveness include doing exercise, having healthy food, using skin lotion, using proper perfume, putting on make-up, or having good personalities. This led to the motivation of this study, to determine the factors associated with behaviors that promote attractiveness in an individual.

Numerous research studies disclose that attractiveness delivers a surplus in terms of advantageous interview and resume evaluations, and ensuing opportunities to get employed including income and financial stability. Although outstanding qualifications are believed to be the most significant criteria in the employment procedure, good-looking individuals with average resumes are more frequently offered an interview than the unappealing individual. Hence, attractiveness seems to have an important influence on selection when several applicants have comparable qualifications. (Beehr \& Gilmore, 1982; Judge, Hurst, \& Simon, 2009; Mobius \& Rosenblat, 2006; Riggio \& Throckmorton, 1988; Watkins \& Johnston, 2000; Jawahar \& Mattsson, 2005). They are more 
persuasive, in part, because they also possess or develop key personality traits like intelligence and social skills. They are also perceived as more likable and trustworthy.

Possessing personality traits that are attractive may be causal in making a face attractive (Little, et al., 2006). Abel, et al. (2009) reported that attractive people are surrounded by pleasant assumptions, for example, having more prominent careers, being more socially expert and intelligent, and better-off in general with their lives. Meta-analyses support the strong effect of physical attractiveness on positive impressions and the "what is beautiful is good" phenomenon (Dion, Berscheid, \& Walster, 1972; Eagly, Ashmore, Makhijani, \& Longo, 1991; Feingold, 1992; Hosoda, Stone-Romero, \& Coats, 2003; Langlois et al., 2000) with the power of the influence apparently similar for both men and women (Langlois et al., 2000). The theory suggested to account for the "what is good is beautiful" phenomenon and with most support is the implicit personality theory (Eagly et al., 1991). Implicit personality theory proposes that people stereotype others on the basis of definite assumptions associated to physical appearances, and so, attractiveness is consequently connected to other positive dimensions of personality such as being more socially adept, interpersonally and occupationally successful, and intelligent. In addition, others seem to respond more positively to physically attractive individuals with subsequent positive outcomes." (Abel et al., 2009).

Hosoda et al., 2003 revealed that there was a significant association between attractiveness and task-related outcomes in both research laboratory and field settings, for both men as well as women, and for both human resource professionals and college students in research laboratory settings. Furthermore, a work by Marlowe et al. (1996) showed that unattractive women are the most disadvantaged on evaluations of job hiring process and possibility of development toward an executive level organizational position which is opposite to the concept of "beauty is beastly" effect suggested by Heilman and Saruwatari (1979). Additionally, Jawahar and Mattsson (2005) showed that a more attractive applicant irrespective of sex is more likely being employed regardless of whether the occupation is male-dominated or female-dominated. In essence, behaviors that promote attractiveness are fruitful and rewarded by societies.

\subsection{Self efficacy}

Bandura (1997) formally defined perceived self-efficacy as personal judgments of one's capabilities to organize and execute courses of action to attain designated goals, and he sought to assess its level, generality, and strength across activities and contexts. Strength of perceived efficacy is measured by the amount of one's certainty about performing a given task. These properties of self-efficacy judgments are measured using questionnaire items that are task specific, vary in difficulty, and capture degrees of confidence. "Self-efficacy is the extent or strength of one's belief in one's own ability to complete tasks and reach goals" (Ormrod, 2006).

According to Caprara et al. (2006), "perceived self-efficacy has proved to play a pivotal role in self-regulation processes" "The findings from diverse lines of research have documented the influential role of self-efficacy beliefs in various domains of functioning such as learning, work, sports, health, social adjustment, and well-being” (Bandura, 1997; 2001).

\subsection{Happiness}

Happiness is one among the most essential elements in life and also this fact has been confirmed by a number of researchers (Aumeboonsuke, 2017). Some of these research studies are the followings. Chida and Steptoe (2008) found that "positive moods such as joy, happiness, and energy, as well as characteristics such as life satisfaction, hopefulness, optimism, and sense of humor, were associated with reduced risk of mortality in healthy populations, and predicted longevity, controlling for negative states" (Diener \& Chan, 2011). Brummett et al.'s (2006) investigation of 4,989 students revealed that optimistic individuals had higher longevity rates compared with pessimistic individuals. Guven and Saloumidis's (2009) "panel study found that the impact of marriage on longevity appeared to be mediated by happiness" (Guven \& Saloumidis 2009). Diener and Chan's (2011) research, entitled "Happy people live longer: Subjective well-being contributes to health and longevity," provided extensive reviews on a number of studies about the benefits of happiness and concluded that there now are sufficient studies about the influence of happiness on health. The effect sizes of subjective well-being are large and therefore happiness should be worthy of attention. Numerous studies found the relationship between happiness and health. This research expands the field of studies on happiness by providing the model that relates happiness with self-efficacy, individual values, and behaviors that promote attractiveness.

\subsection{Individual Values}

Important theorists in a variety of fields have emphasized the importance of people's value priorities in understanding and predicting attitudinal and behavioral decisions. For example, Gordon Allport (1961) 
suggested that value priorities were the "dominating force in life" (p. 543) because they directed all of a person's activity toward their realization (Rohan, 2000). See Appendix A for a selection of values definitions.

According to Rohan (2000), "Schwartz (1992) identified a comprehensive set of basic values that are recognized in all societies and defined basic values as trans-situational goals, varying in importance, that serve as guiding principles in the life of a person or group. He theorized that basic values are organized into a coherent system that underlies and can help to explain individual decision making, attitudes, and behavior. This coherent structure arises from the social and psychological conflict or congruity between values that people experience when they make everyday decisions (Schwartz, 1992, 2006). The 10 basic values identified in the theory are self-direction, stimulation, hedonism achievement, power, security, conformity, tradition, benevolence, and universalism. (see Appendix B for definitions of each one)". These values are likely to be universal because they are grounded in one or more of three universal requirements of human existence with which people must cope: needs of individuals as biological organisms, requisites of coordinated social interaction, and survival and welfare needs of groups. Each value is grounded in one or more of these three universal requirements of human existence. All of the studies that employ the theory of basic values treat the 10 values as discrete entities.

This research measured value in each aspect regarding previous literatures and tested the impact of individual's happiness and self-efficacy on one's value, and also whether individual values encourage him/her to engage in behaviors that promote his/her attractiveness (see figure 1).

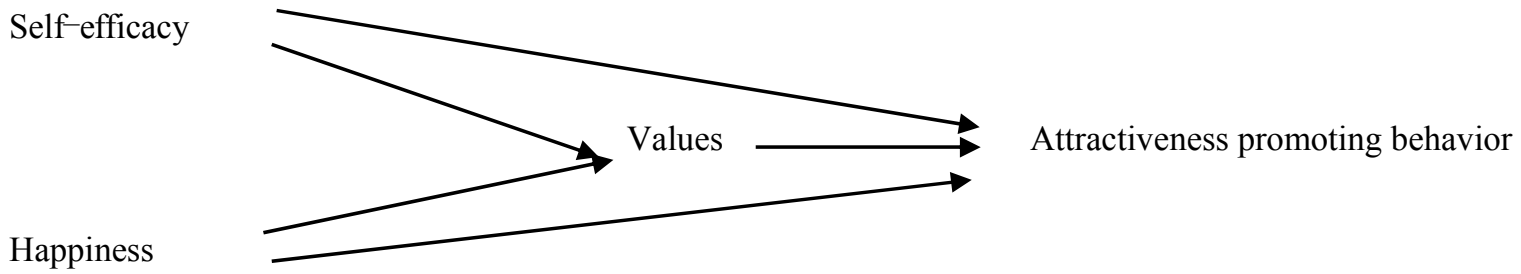

Figure 1. Research Model

In addition, the analysis of whether the individual values contribute to the moderating effect between each predictor and attractiveness promoting behavior was also examined.

Control variables include physical background, demographic background and geographic background such as age, gender, type of city where participant grows up, academic grade, and weight height ratio.

Hypotheses in this study were the followings:

Hypothesis 1: There is a positive relationship between self-efficacy and individual values.

Hypothesis 2: There is a positive relationship between happiness and individual values.

Hypothesis 3: There is a positive relationship between self-efficacy and attractiveness promoting behavior.

Hypothesis 4: There is a positive relationship between happiness and attractiveness promoting behavior.

Hypothesis 5: There is a positive relationship between values and attractiveness promoting behavior.

\section{Data and Methodology}

\subsection{Data}

The participants of this research are undergrad students from several leading universities in Thailand whose age range between 18 to 24 years old. The data were collected through self administered questionnaires survey. The total of 360 usable questionnaires were obtain. Descriptive statistics of demographic information of the sample are reported in Table 1.

Table 1. Demographic Information of Sample

\begin{tabular}{cc}
\hline Gender & Male: $72(28 \%)$ \\
& Female: $185(72 \%)$ \\
\hline \multirow{2}{*}{ Age } & Mean: 21.34 \\
& Standard deviation: 3.20 \\
\hline City & Urban: $127(49.42 \%)$ \\
\hline
\end{tabular}


Suburban: $75(29.18 \%)$

Rural: $55(21.40 \%)$

\begin{tabular}{cc} 
& Rural: $55(21.40 \%)$ \\
\hline \multirow{2}{*}{ Average grade } & A: $32(12.45 \%)$ \\
& B: $133(51.75 \%)$ \\
& C: $89(34.63 \%)$ \\
D: $3(1.17 \%)$ \\
\hline \multirow{2}{*}{ Height } & Mean: $164.13 \mathrm{~cm}$. \\
& Standard deviation: 8.73 \\
\hline \multirow{2}{*}{ Weight } & Mean: $53.51 \mathrm{~kg}$. \\
& Standard deviation: 10.41 \\
\hline \multirow{2}{*}{ Height/weight ratio } & Mean: 3.17 \\
& Standard deviation: 0.62 \\
\hline
\end{tabular}

\subsection{Measures}

Behaviors that promote attractiveness was measured by asking the respondents to indicate how often they are engaged in a set of twelve items of behaviors. The level of frequency in each item was measured using an ordinal scale ranged from 1 (not at all) to 5 (everyday). The sample items included "How often do you engage in doing exercise?", "How often do you engage in eating healthy food?", "How often do you use skin lotion?", "How often do you use body freshener/perfume?", and "How often do you put on make-up?".

Individual values were measured by asking the respondents to indicate the level of their values on a set of twenty items. The level of values in each item was measured using an ordinal scale ranged from 1 (not at all) to 5 (very much). The question was "How much each aspect is important for you?" and the sample aspects included having good looks, being beautiful, being sexy, being talented, having a good personality, having a sense of humor, having good social skills, and having close friends you can confide in.

Self-efficacy was measured by asking the respondents to indicate the level of their self-efficacy on a set of eighteen items based on Bandura (2006). The level of self-efficacy in each item was measured using an ordinal scale ranged from 1 (not at all) to 7 (very well). The sample items included "How well can you bounce back after you tried your best and failed?," "How well can you overcome discouragement when nothing you try seems to work?," "How well can you develop good communication and social skills?," "How well can you exercise to be healthy and full of energy?," "How well can you maintain a sincere/true relationship with your friends?," and "How well can you maintain a close relationship with your parents?"

Happiness was measured by asking respondents to indicate how happy they are with several aspects in their lives by using a set of sixteen items, including "I have a happy family," "I have close friends that understand me," "I am healthy," "I am proud of what I have achieved," "I am happy with my job prospects," and "I am liked by the people around me." They were scored on seven-point frequency scale ranging from 1 (not at all) to 7 (very much).

The items in each factor were used to construct a reflective latent variable of their construct and were tested for reliability and validity.

\subsection{Statistical Analysis}

The impact of self-efficacy and one's happiness on individual values and attractiveness promoting behavior was analyzed through the partial least squared structural equation modeling (PLS-SEM). The PLS-SEM analysis was performed by using the $\mathrm{R}$ program.

PLS-SEM is a causal modeling method with the objective to explain variance of the dependent latent constructs. There are two components in the PLS-SEM Algorithm. The first component is the structural model (the inner model) that expresses the relationships (paths) between the latent constructs which can be exogenous or endogenous constructs. Exogenous describes latent constructs that are explained by other constructs via structural model relationships. The second component comprises the measurement models (the outer model) which include the unidirectional predictive relationships between each latent construct and its associated observed indicators (Hair et al., 2011). 
PLS was appropriate for the data used in this research because of three reasons. First, the independent variables and dependent variables in the study are latent variables that quantify attitudes and the PLS-SEM analysis is suitable to perform path model on cause-effect relationships among latent constructs (Hair et al., 2011). Second, it is not the requirement for PLS-SEM to have a large sample size, unlike other SEM techniques (Chin, 1998; Goodhue et al., 2006). And third, PLS-SEM does not assume that the data is normally distributed (Bovaird et al., 2007).

\section{Findings \& Discussions}

The first and the second model analyzes the relationship among the variables without interaction terms. Convergence validity was analyzed by using factor loadings. Hair et al. (2006) suggested that the value of factor loadings should be higher than 0.5 . The results shown in Table 2 to Table 4 indicate that all factor loadings except for one item of self-efficacy and two items of value were above the minimum requirement. The three items that had low loading were removed from the analysis. Table 5 indicates that three factor loadings were above the threshold requirement so these three items were included in the analysis.

Table 2. Factor Loadings for Eighteen Items in Self-Efficacy (x1)

\begin{tabular}{ccc}
\hline Name & Weight & Loading \\
\hline Section4.1 & 0.0791 & 0.5250 \\
Section4.2 & 0.0683 & 0.5260 \\
Section4.3 & 0.0805 & 0.5800 \\
Section4.4 & 0.0566 & 0.5280 \\
Section4.5 & 0.0500 & 0.4820 \\
Section4.6 & 0.0870 & 0.6000 \\
Section4.7 & 0.1972 & 0.7100 \\
Section4.8 & 0.0342 & 0.6180 \\
Section4.9 & 0.0617 & 0.5070 \\
Section4.10 & 0.1200 & 0.6340 \\
Section4.11 & 0.0833 & 0.6310 \\
Section4.12 & 0.0756 & 0.6010 \\
Section4.13 & 0.2014 & 0.7470 \\
Section4.14 & 0.0956 & 0.6870 \\
Section4.15 & 0.0634 & 0.5870 \\
Section4.16 & 0.0370 & 0.5220 \\
Section4.17 & 0.0643 & 0.7420 \\
Section4.18 & 0.1268 & 0.6540 \\
\hline
\end{tabular}

Table 3. Factor Loadings for Sixteen Items in Happiness (x2)

\begin{tabular}{ccc}
\hline Name & Weight & Loading \\
\hline Section.6.1 & 0.0867 & 0.5500 \\
Section.6.2 & 0.1042 & 0.5470 \\
Section.6.3 & 0.1325 & 0.7130 \\
Section.6.4 & 0.1497 & 0.7910 \\
Section.6.5 & 0.1021 & 0.6880 \\
Section.6.6 & 0.0722 & 0.6050 \\
Section.6.7 & 0.0989 & 0.6740 \\
Section.6.8 & 0.0701 & 0.5880 \\
\hline
\end{tabular}




\begin{tabular}{ccc}
\hline Section.6.9 & 0.0778 & 0.6420 \\
Section.6.10 & 0.0438 & 0.5720 \\
Section.6.11 & 0.1014 & 0.6230 \\
Section.6.12 & 0.0773 & 0.6360 \\
Section.6.13 & 0.1084 & 0.7320 \\
Section.6.14 & 0.0863 & 0.6930 \\
Section.6.15 & 0.0752 & 0.5950 \\
Section.6.16 & 0.1188 & 0.7500 \\
\hline
\end{tabular}

Table 4. Factor Loadings for Sixteen Items in Individual Values (y1)

\begin{tabular}{ccc}
\hline Name & Weight & Loading \\
\hline Section.9.1 & 0.0780 & 0.7180 \\
Section.9.2 & 0.0615 & 0.7430 \\
Section.9.3 & 0.0490 & 0.5690 \\
Section.9.4 & 0.1241 & 0.8130 \\
Section.9.5 & 0.1330 & 0.7340 \\
Section.9.6 & 0.1353 & 0.8200 \\
Section.9.7 & 0.1310 & 0.6850 \\
Section.9.8 & 0.1378 & 0.7530 \\
Section.9.9 & -0.0179 & 0.3500 \\
Section.9.10 & 0.0601 & 0.6240 \\
Section.9.11 & 0.0790 & 0.6470 \\
Section.9.12 & 0.1008 & 0.6340 \\
Section.9.13 & 0.0939 & 0.5900 \\
Section.9.14 & 0.1399 & 0.7800 \\
Section.9.15 & 0.1025 & 0.5620 \\
Section.9.16 & -0.0034 & 0.2220 \\
\hline
\end{tabular}

Table 5. Factor Loadings for Sixteen Items in Attractiveness Promoting Behavior (y2)

\begin{tabular}{ccc}
\hline Name & Weight & Loading \\
\hline Section.10.1 & 0.0252 & 0.1130 \\
Section.10.2 & -0.0188 & 0.0544 \\
Section.10.3 & -0.0020 & 0.1268 \\
Section.10.4 & 0.3254 & 0.7870 \\
Section.10.5 & 0.3539 & 0.7804 \\
Section.10.6 & -0.0902 & -0.1260 \\
Section.10.7 & -0.1418 & -0.3375 \\
Section.10.8 & -0.0036 & -0.1049 \\
Section.10.9 & -0.1194 & -0.3093 \\
Section.10.10 & 0.3089 & 0.8061 \\
Section.10.11 & 0.0751 & 0.2885 \\
Section.10.12 & 0.2403 & 0.4116 \\
\hline
\end{tabular}


Diagnostic tests have been performed by discriminant validity, construct validity, and reliability. Discriminant validity was analyzed by comparing the average variance extracted (AVE) to the squared correlation coefficient. Fornell and Larcker (1981) suggested that the square root of the AVE must be greater than correlations between the constructs in order for discriminant validity to be satisfied. The results shown in Table 6 indicate that all the values of the square root of the AVE (values in the main diagonal line) were greater than the correlations between the constructs except for one case in $\mathrm{p} 1$ where the difference was trivial. Construct validity was analyzed by applying Cronbach's alpha coefficients and Dillon-Goldstein's rho. The minimum requirement for these two indicators was 0.7 . The results shown in Table 7 show that the reliability indicators of all latent variables were acceptable according to Nummally (1978).

Table 6. Squared Root of the AVE and Correlations Between the Constructs

\begin{tabular}{|c|c|c|c|c|c|c|c|c|c|}
\hline & $\mathrm{x} 1$ & $\mathrm{x} 2$ & $\mathrm{z} 1$ & $\mathrm{z} 2$ & $\mathrm{z3}$ & $\mathrm{z} 4$ & $\mathrm{z} 5$ & $\mathrm{y} 1$ & $\mathrm{y} 2$ \\
\hline $\mathrm{x} 1$ & 0.5933 & & & & & & & & \\
\hline $\mathrm{x} 2$ & 0.6293 & 0.6550 & & & & & & & \\
\hline z1 & 0.1989 & 0.1647 & 1.0000 & & & & & & \\
\hline $\mathrm{z} 2$ & -0.0222 & 0.0621 & -0.0730 & 1.0000 & & & & & \\
\hline z3 & 0.0818 & 0.0015 & 0.0325 & 0.1275 & 1.0000 & & & & \\
\hline $\mathrm{z} 4$ & -0.0693 & -0.1196 & -0.0783 & 0.0163 & 0.2807 & 1.0000 & & & \\
\hline $\mathrm{z} 5$ & 0.1799 & 0.1647 & 0.4892 & -0.1699 & 0.0226 & -0.1554 & 1.0000 & & \\
\hline y1 & 0.2409 & 0.3223 & -0.1021 & 0.1031 & -0.1546 & -0.1704 & -0.1044 & 0.6841 & \\
\hline y2 & 0.2712 & 0.1601 & 0.5719 & -0.0522 & 0.1185 & -0.0264 & 0.4401 & 0.0230 & 0.4461 \\
\hline
\end{tabular}

Table 7. Cronbach's Alphas Coefficient and Dillon-Goldstein's Rho

\begin{tabular}{ccc}
\hline & C.alpha & DG.rho \\
\hline Self-efficacy & 0.8970 & 0.9118 \\
Happiness & 0.9100 & 0.9227 \\
Individual values & 0.9180 & 0.9300 \\
Attractiveness promoting behavior & 0.2120 & 0.0004 \\
\hline
\end{tabular}

The results from the PLS analysis of the first model are summarized in Table 8. Standardized path coefficients and $\mathrm{p}^{-}$-values are reported. Table 8 and table 9 report the results from model one and model two, respectively. Model one focuses on the impact of self-efficacy and happiness on individual values whereas model two emphasizes on the impact of self-efficacy and happiness on attractiveness promoting behavior. The results show that happiness has a significant positive association with individual values whereas self-efficacy has a significant positive association with attractiveness promoting behavior.

Table 8. PLS results on Model One

\begin{tabular}{llllll}
\hline & Estimate & Std. Error & $\mathrm{t}$ value & $\operatorname{Pr}(\ngtr|\mathrm{t}|)$ & Sig \\
\hline Intercept & 0.0000 & 0.0690 & 0.0000 & 1.0000 & \\
Self-efficacy & 0.0895 & 0.0908 & 0.9859 & 0.3256 & \\
Happiness & 0.2421 & 0.0919 & 2.6326 & 0.0092 & $* * *$ \\
z1 & -0.1290 & 0.0795 & -1.6228 & 0.1064 & \\
z2 & 0.0920 & 0.0715 & 1.2868 & 0.1999 & \\
z3 & -0.1452 & 0.0732 & -1.9818 & 0.0491 & $* *$ \\
z4 & -0.1247 & 0.0734 & -1.6995 & 0.0910 & $*$ \\
z5 & -0.0924 & 0.0814 & -1.1360 & 0.2575 & \\
\hline
\end{tabular}

Note. $* * *=\mathrm{p}<0.01, * *=\mathrm{p}<0.05, *=\mathrm{p}<0.10$,

$\mathrm{z} 1^{-} \mathrm{z} 5$ are control variables including gender, age, type of city grown from, and academic performance. 
Table 9. PLS Results on Model Two

\begin{tabular}{cccccc}
\hline & Estimate & Std.Error & t value & $\operatorname{Pr}(\gamma|\mathrm{t}|)$ & Sig \\
\hline Intercept & 0.0000 & 0.0581 & 0.0000 & 1.0000 & \\
Self-efficacy & 0.2370 & 0.0735 & 3.2260 & 0.0015 & $* * *$ \\
Happiness & -0.0597 & 0.0716 & -0.8336 & 0.4057 & \\
z1 & 0.4132 & 0.0683 & 6.0510 & 0.0000 & $* * *$ \\
z2 & 0.0074 & 0.0598 & 0.1235 & 0.9019 & \\
z3 & 0.0707 & 0.0616 & 1.1469 & 0.2530 & \\
z4 & 0.0252 & 0.0619 & 0.4070 & 0.6845 & \\
z5 & 0.2025 & 0.0687 & 2.9471 & 0.0036 & \\
\hline
\end{tabular}

Note. $* * *=\mathrm{p}<0.01, * *=\mathrm{p}<0.05, *=\mathrm{p}<0.10$,

$\mathrm{z} 1^{-} \mathrm{z} 5$ are control variables including gender, age, type of city grown from, and academic performance.

The third model analyzed the associations among variables with interaction terms. Convergence validity and discriminant validity were analyzed in a way similar to that in the first model. Most of the factor loadings were satisfactory and the items that had a low loading were removed from the analysis. Construct validity was analyzed using Cronbach's alpha coefficients and Dillon-Goldstein's rho. The results indicate that the reliability indicators of all latent variables were satisfactory.

The results from the PLS analysis on the third model are presented in Table 10. Standardized path coefficients and $\mathrm{p}$-values are described.

Table 10. PLS Results on Model Three

\begin{tabular}{|c|c|c|c|c|c|}
\hline \multicolumn{6}{|c|}{ Dependent variable $=$ Individual values } \\
\hline & Estimate & Std.Error & t value & $\operatorname{Pr}(>|t|)$ & Sig \\
\hline Intercept & 0.0000 & 0.0707 & 0.0000 & 1.0000 & \\
\hline Self-efficacy & 0.0631 & 0.0909 & 0.6936 & 0.4888 & \\
\hline Happiness & 0.2826 & 0.0909 & 3.1088 & 0.0022 & $* * *$ \\
\hline \multicolumn{6}{|c|}{ Dependent variable $=$ Attractive promoting behavior } \\
\hline & Estimate & Std.Error & t value & $\operatorname{Pr}(\gamma|t|)$ & \\
\hline Intercept & -0.0000 & 0.0589 & -0.0000 & 1.0000 & \\
\hline Self-efficacy & 0.1646 & 0.0775 & 2.1231 & 0.0352 & $* *$ \\
\hline happiness & -0.0821 & 0.0788 & -1.0417 & 0.2990 & \\
\hline $\mathrm{z} 1$ & 0.4579 & 0.0685 & 6.6817 & 0.0000 & $* * *$ \\
\hline $\mathrm{z} 2$ & 0.0042 & 0.0611 & 0.0688 & 0.9453 & \\
\hline $\mathrm{z} 3$ & 0.0901 & 0.0632 & 1.4256 & 0.1558 & \\
\hline $\mathrm{z} 4$ & 0.0358 & 0.0631 & 0.5670 & 0.5714 & \\
\hline $\mathrm{z} 5$ & 0.2146 & 0.0699 & 3.0675 & 0.0025 & $* * *$ \\
\hline Individual values & 0.0985 & 0.0654 & 1.5074 & 0.1335 & \\
\hline
\end{tabular}

Note. $* * *=\mathrm{p}<0.01, * *=\mathrm{p}<0.05, *=\mathrm{p}<0.10$,

$\mathrm{z} 1^{-} \mathrm{z} 5$ are control variables including gender, age, type of city grown from, and academic performance.

Table 10 illustrates the results of the third model that simultaneously analyzed the impact of selfefficacy and happiness on individual values and attractiveness promoting behavior. The empirical hypothesis examined under the third model is summarized in the following section: 
Hypothesis 1 predicted that self-efficacy increases individual values. The results from the PLS estimation indicated that the association these two variables were statistically insignificant (beta $=0.0895 ; \mathrm{p}=0.3256$ for the first model and beta $=0.0631 ; \mathrm{p}=0.4888$ for the third model). Thus, hypothesis 1 was not supported.

Hypothesis 2 predicted that happiness increases individual values. The results from the PLS estimation indicated that these two variables were positively related; the association was also statistically significant (beta $=2.2421$; $\mathrm{p}=0.0092$ for the first model and beta $=0.2826 ; \mathrm{p}=0.0022$ for the third model). Thus, hypothesis 2 was supported.

Hypothesis 3 predicted that self-efficacy increases attractiveness promoting behavior. The results from the PLS estimation indicated that these two variables were positively related; the association was also statistically significant ( $b e t a=0.2370 ; \mathrm{p}=0.0015$ for the second model and beta $=0.1646 ; \mathrm{p}=0.0352$ for the third model). Thus, hypothesis 3 was supported.

Hypothesis 4 predicted that happiness increases attractiveness promoting behavior. The results from the PLS estimation indicated that these two variables were statistically insignificant (beta $=-0.0597 ; p=0.4057$ for the second model and beta $=-0.0821 ; \mathrm{p}=0.2990$ for the third model). Thus, hypothesis 4 was not supported.

Hypothesis 5 predicted that individual values increases attractiveness promoting behavior. The results from the PLS estimation indicated that these two variables were statistically insignificant (beta $=0.0985 ; \mathrm{p}=0.1335$ for the third model). Thus, hypothesis 5 was not supported.

The results show that happiness has strong significant positive impact on individual values but not on attractive promoting behavior. Whereas self-efficacy has strong significant positive impact on attractive promoting behavior but not on individual values.

The findings provide important implications that both self-efficacy and happiness are important in one.s life but they play different and independent roles. The results found that individual values and attractiveness promoting behavior are independent and they have no significant association with each other. In addition, in order for an individual to achieve higher level of individual values, psychological and mental factor like happiness should be paid much more attention than perceived ability like self-efficacy. However, in order for an individual to engage oneself in behaviors that promote his/her attractiveness, perceived ability like self-efficacy is the key factor. In other words, a person who is happier but has lower level of self-efficacy tend to have more value in oneself. Whereas a person who has higher level of self-efficacy but is less happy tend to involve more in behaviors that promote his/her attractiveness.

\section{Concluding Remarks}

The objective of this research was to investigate the role of self-efficacy and happiness in promoting individual values and how one engages in behaviors that promote attractiveness. The author proposed that self-efficacy and happiness would contribute to individual values and individual's engagements in behaviors that promote attractiveness. In addition, the author also proposed that there is interrelationship between individual values and engagement in behaviors that promote attractiveness. The statistical evidence revealed that happiness had a strong positive impact on individual values whereas happiness was not significantly related to one's engagement in attractiveness promoting behavior. On the contrary, self-efficacy had a strong positive impact on one's engagement in attractiveness promoting behavior whereas selfefficacy was not significantly related to individual values. In addition, individual values and engagement in behaviors that promote attractiveness are independent to each other.

In conclusion, the results from this research provide some recommendations for individuals regarding the approach to individual values and engagements in behaviors that promote attractiveness. The results indicated that both self-efficacy and happiness are significant factors but they play different roles and they are independent A person who is happy tend to have more value in oneself even though he/she has low self-efficacy. Whereas a person who is less happy tend to involve more in behavior that promote attractive, given that he/she has higher level of self-efficacy. It can be seen clearly that there is no one perfect answer for all quests. In essence, individuals who emphasis more in one's value should pay more attention to how to make oneself be happy while individuals who emphasis more in engaging oneself in behaviors that promote attractiveness should focus on improving their self-efficacy.

\section{References}

Abel, M. H., Croysdale, A., \& Stiles, S. (2009). The Influence of Physical Attractiveness on Promotion Recommendations in Male and Female Applicants. American Journal of Psychological Research, 5(1), 97-110. 
Allport, G. W. (1961). Values and our youth. Teachers College Record, 63. 211-219.

Aumeboonsuke, V. (2017). Parents or peers, wealth or warmth?: the impact of social support, wealth, and a positive outlook on self-efficacy and happiness. International Journal of Social Economics, 44(6), forthcoming. https://doi.org/10.1108/IJSE-01-2015-0002

Bandura, A. (1997). Self-efficacy: The exercise of control. Freeman: New York.

Bandura A. (2001). Social cognitive theory: An agentic perspective. Annual Review of Psychology, 52, 1-26. https://doi.org/10.1146/annurev.psych.52.1.1

Bandura, A. (2006). Guide for constructing self-efficacy scales. Self-efficacy beliefs of adolescents, 5(307-337).

Beehr, T. A., \& Gilmore, D. C. (1982). Applicant Attractiveness as a Perceived Job-Relevant Variable in Selection of Management Trainees1. Academy of Management Journal, 25(3), 607-617. https://doi.org/10.2307/256084

Bovaird, J., Kupzyk, K., Maikranz, J., Dreyer, M., \& Steele, R. (2007). Missing data and standard errors with partial least squares. In 115th annual meeting of the American Psychological Association, San Francisco.

Brummett, B. H., Babyak, M. A., Siegler, I. C., Vitaliano, P. P., Ballard, E. L., Gwyther, L. P., \& Williams, R. B. (2006). Associations among perceptions of social support, negative affect, and quality of sleep in caregivers and noncaregivers. Health Psychology, 25(2), 220. https://doi.org/10.1037/0278-6133.25.2.220

Caprara, G. V., Steca, P., Gerbino, M., Paciello, M., \& Vecchio, G. M. (2006). Looking for adolescents' well-being: Self-efficacy beliefs as determinants of positive thinking and happiness. Epidemiologia e psichiatria sociale, 15(1), 30-43. https://doi.org/10.1017/S1121189X00002013

Chida, Y., \& Steptoe, A. (2008). Positive psychological well-being and mortality: a quantitative review of prospective observational studies. Psychosomatic Medicine, 70(7), 741-756. https://doi.org/10.1097/PSY.0b013e31818105ba

Chin, W. W. (1998). Commentary: Issues and opinion on structural equation modeling. MIS Quarterly, 22(1), vii-xvi.

Diener, E., \& Chan, M. Y. (2011). Happy people live longer: Subjective well - being contributes to health and longevity. Applied Psychology: Health and Well - Being, 3(1), 1-43. https://doi.org/10.1111/j.1758-0854.2010.01045.x

Dion, K., Berscheid, E., \& Walster, E. (1972). What is beautiful is good. Journal of Personality and Social Psychology, 24(3), 285. https://doi.org/10.1037/h0033731

Eagly, A. H., Ashmore, R. D., Makhijani, M. G., \& Longo, L. C. (1991). What is beautiful is good, but...: A meta-analytic review of research on the physical attractiveness stereotype. Psychological bulletin, 110(1), 109. https://doi.org/10.1037/0033-2909.110.1.109

Feingold, A. (1992). Good-looking people are not what we think. Psychological bulletin, 111(2), 304. https://doi.org/10.1037/0033-2909.111.2.304

Fornell, C., \& Larcker, D. F. (1981). Structural equation models with unobservable variables and measurement error: Algebra and statistics. Journal of marketing research, 382-388. https://doi.org/10.2307/3150980

Goodhue, D., Lewis, W., \& Thompson, R. (2006, January). PLS, Small Sample Size, and Statistical Power in MIS Research. In Proceedings of the 39th Annual Hawaii International Conference on System Sciences-Volume 08 (pp. 202-2). IEEE Computer Society. https://doi.org/10.1109/HICSS.2006.381

Guven, C., \& Saloumidis, R. (2009). Why is the world getting older? The influence of happiness on mortality (No. 2009_03). Deakin University, Faculty of Business and Law, School of Accounting, Economics and Finance. https://doi.org/10.2139/ssrn.1422489.

Hair, J. F., Tatham, R. L., Anderson, R. E., \& Black, W. (2006). Multivariate data analysis (Vol. 6). Upper Saddle River, NJ: Pearson Prentice Hall.

Hair, J. F., Ringle, C. M., \& Sarstedt, M. (2011). PLS-SEM: Indeed a silver bullet. Journal of Marketing Theory and Practice, 19(2), 139-152. https://doi.org/10.2753/MTP1069-6679190202

Heilman, M. E., \& Saruwatari, L. R. (1979). When beauty is beastly: The effects of appearance and sex on evaluations of job applicants for managerial and nonmanagerial jobs. Organizational Behavior and Human Performance, 23(3), 360-372. https://doi.org/10.1016/0030-5073(79)90003-5 
Hönekopp, J. (2006). Once more: is beauty in the eye of the beholder? Relative contributions of private and shared taste to judgments of facial attractiveness. Journal of Experimental Psychology: Human Perception and Performance, 32(2), 199. https://doi.org/10.1037/0096-1523.32.2.199

Hosoda, M., Stone-Romero, E. F., \& Coats, G. (2003). The effects of physical attractiveness on job - related outcomes: A meta-analysis of experimental studies. Personnel Psychology, 56(2), 431-462. https://doi.org/10.1111/j.1744-6570.2003.tb00157.x

Jawahar, I. M., \& Mattsson, J. (2005). Sexism and beautyism effects in selection as a function of self-monitoring level of decision maker. Journal of Applied Psychology, 90(3), 563. https://doi.org/10.1037/0021-9010.90.3.563

Judge, T. A., Hurst, C., \& Simon, L. S. (2009). Does it pay to be smart, attractive, or confident (or all three)? Relationships among general mental ability, physical attractiveness, core self-evaluations, and income. Journal of Applied Psychology, 94(3), 742. https://doi.org/10.1037/a0015497

Langlois, J. H., Kalakanis, L., Rubenstein, A. J., Larson, A., Hallam, M., \& Smoot, M. (2000). Maxims or myths of beauty? A meta-analytic and theoretical review. Psychological bulletin, 126(3), 390. https://doi.org/10.1037/0033-2909.126.3.390

Little, A. C., Burt, D. M., \& Perrett, D. I. (2006). What is good is beautiful: Face preference reflects desired personality. Personality and Individual Differences, 41(6), 1107-1118. https://doi.org/10.1016/j.paid.2006.04.015

Marlowe, C. M., Schneider, S. L., \& Nelson, C. E. (1996). Gender and attractiveness biases in hiring decisions: Are more experienced managers less biased?. Journal of applied psychology, 81(1), 11. https://doi.org/10.1037/0021-9010.81.1.11

Mobius, M. M., \& Rosenblat, T. S. (2006). Why beauty matters. The American Economic Review, 96(1), 222-235. https://doi.org/10.1257/000282806776157515

Nummally, J. C. (1978). Psychometric theory. New York, NY: McGraw-Hill.

Ormrod, J. E. (2006). Educational psychology: Developing learners (5th ed.). Upper Saddle River, N.J.: Pearson/Merrill Prentice Hall.

Ormrod, J. E. (2006). Essentials of educational psychology. Pearson Merrill Prentice Hall.

Riggio, R. E., \& Throckmorton, B. (1988). The Relative Effects of Verbal and Nonverbal Behavior, Appearance, and Social Skills on Evaluations Made in Hiring Interviews1. Journal of Applied Social Psychology, 18(4), 331-348. https://doi.org/10.1111/j.1559-1816.1988.tb00020.x

Rohan, M. J. (2000). A rose by any name? The values construct. Personality and social psychology review, 4(3), 255-277. https://doi.org/10.1207/S15327957PSPR0403_4

Schwartz, S. H. (1992). Universals in the content and structure of values: Theoretical advances and empirical tests in 20 countries. Advances in experimental social psychology, 25, 1-65. https://doi.org/10.1016/S0065-2601(08)60281-6

Schwartz, S. H. (2006). A theory of cultural value orientations: Explication and applications. Comparative sociology, 5(2), 137-182. https://doi.org/10.1163/156913306778667357

Schwartz, S. H., Cieciuch, J., Vecchione, M., Davidov, E., Fischer, R., Beierlein, C., ... \& Dirilen-Gumus, O. (2012). Refining the theory of basic individual values. Journal of personality and social psychology, 103(4), 663. https://doi.org/10.1037/a0029393

Watkins, L. M., \& Johnston, L. (2000). Screening job applicants: The impact of physical attractiveness and application quality. International Journal of Selection and Assessment, 8(2), 76-84. https://doi.org/10.1111/1468-2389.00135

Zimmerman, B. J. (2000). Self-efficacy: An essential motive to learn. Contemporary educational psychology, 25(1), 82-91. https://doi.org/10.1006/ceps.1999.1016 


\section{Appendix A}

\section{A Selection of Values Definitions}

Conceptual Definitions of 10 Basic Values According to Their Motivational Goals and Components of the Definitions That Suggest Subtypes of Values

\begin{tabular}{|c|c|c|}
\hline Value & Conceptual definition ${ }^{\mathrm{a}}$ & Definition components \\
\hline Self-direction & Independent thought and action-choosing, creating, exploring & $\begin{array}{l}\text { Autonomy of thought } \\
\text { Autonomy of action }\end{array}$ \\
\hline Stimulation & Excitement, novelty, and challenge in life & $\begin{array}{l}\text { Excitement } \\
\text { Novelty } \\
\text { Challenge }\end{array}$ \\
\hline Hedonism & Pleasure and sensuous gratification for oneself. & Single component: Pleasure \\
\hline Achievement & Personal success through demonstrating competence according to social standards & $\begin{array}{l}\text { Personal success } \\
\text { Demonstrating compatence }\end{array}$ \\
\hline Power & Social status and prestige, control or dominance over people and resources & $\begin{array}{l}\text { Dominance over people } \\
\text { Control of material resources } \\
\text { Face: Status and prestige }\end{array}$ \\
\hline Security & Safety, harmony, and stability of society, of relationships, and of self & $\begin{array}{l}\text { Societal security } \\
\text { Personal security }\end{array}$ \\
\hline Conformity & $\begin{array}{l}\text { Restraint of actions, inclinations, and impulses likely to upset or harm others and } \\
\text { violate social expectations or norms }\end{array}$ & $\begin{array}{l}\text { Interpersonal: Avoiding upsetting others } \\
\text { Compliance with social norms }\end{array}$ \\
\hline Tradition & $\begin{array}{l}\text { Respect, commitment, and acceptance of the customs and ideas that traditional } \\
\text { culture or religion provides }\end{array}$ & $\begin{array}{l}\text { Single component: Maintaining cultural } \\
\text { and religious traditions }\end{array}$ \\
\hline Benevolence & $\begin{array}{l}\text { Preservation and enhancement of the welfare of people with whom one is in } \\
\text { frequent personal contact }\end{array}$ & $\begin{array}{l}\text { Single component: Caring for ingroup } \\
\text { members }\end{array}$ \\
\hline Universalism & $\begin{array}{l}\text { Understanding, appreciation, tolerance and protection for the welfare of all } \\
\text { pecple and for nature }\end{array}$ & $\begin{array}{l}\text { Tolerance } \\
\text { Societal concern } \\
\text { Protecting nature }\end{array}$ \\
\hline
\end{tabular}

a Definitions in column 2 are adapted from "Are There Universal Aspects in the Content and Structure of Values?" by S. H. Schwartz, 1994, Journal of Social Issues, 50, p. 22. Copyright 1994 by John Wiley \& Sons, Inc.

Source. Schwartz, S. H., Cieciuch, J., Vecchione, M., Davidov, E., Fischer, R., Beierlein, C., ... \& Dirilen-Gumus, O. (2012). Refining the theory of basic individual values. J. of personality and social psychology, $103(4), 663$.

\section{Appendix B}

\section{Definitions of 10 Basic Values}

\begin{tabular}{|c|c|}
\hline Theorist & Definition \\
\hline Lewin $(1952$, p. 41$)$ & $\begin{array}{l}\text { Values influence behavior but have not the character of a goal (i.e., of a force field). For } \\
\text { example, the individual does not try to "reach" the value of fairness, but faimess is "guiding" } \\
\text { his behavior. It is probably correct to say that values determine which types of activity have a } \\
\text { positive and which have a negative valence for an individual in a given situation. In other } \\
\text { words, values are not force fields but they "induce" force fields. That means values are } \\
\text { constructs that have the same psychological dimension as power fields. }\end{array}$ \\
\hline C. K. M. Kluckhohn (1951, p. 395) & $\begin{array}{l}\text { A value is a conception, explicit or implicit, distinctive of an individual or characteristic of a } \\
\text { group, of the desirable that influences the selection from available modes, means, and ends of } \\
\text { actions. }\end{array}$ \\
\hline Heider (1958, p. 223) & $\begin{array}{l}\text { We shall use the term value as meaning the property of an entity ( } x \text { has values) or as meaning a } \\
\text { class of entities ( } x \text { is a value) with the connotation of being objectively positive in some way. }\end{array}$ \\
\hline Rokeach (1973, p. 5) & $\begin{array}{l}\text { A value is an enduring belief that a specific mode of conduct or end-state of existence is } \\
\text { personally or socially preferable to an opposite or converse mode of conduct or end-state of } \\
\text { existence. }\end{array}$ \\
\hline Feather (1996, p. 222) & $\begin{array}{l}\text { I regard values as beliefs about desirable or undesirable ways of behaving or about the } \\
\text { desirability or otherwise of general goals. }\end{array}$ \\
\hline Schwartz (1994, p. 21) & $\begin{array}{l}\text { I define values as desirable transsituational goals, varying in importance, that serve as guiding } \\
\text { principles in the life of a person or other social entity. }\end{array}$ \\
\hline Schwartz (1999, p. 24) & $\begin{array}{l}\text { I define values as conceptions of the desirable that guide the way social actors (e.g., organizational } \\
\text { leaders, policy-makers, individual persons) select actions, evaluate people and events, and } \\
\text { explain their actions and evaluations. }\end{array}$ \\
\hline
\end{tabular}

Source. Rohan, M. J. (2000). A rose by any name? The values construct. Personality and social psychology review, 4(3), 255-277.

\section{Copyrights}

Copyright for this article is retained by the author(s), with first publication rights granted to the journal.

This is an open-access article distributed under the terms and conditions of the Creative Commons Attribution license (http://creativecommons.org/licenses/by/4.0/). 